\title{
Begging and Transfer of Coati Meat by White-faced Capuchin Monkeys, Cebus capucinus
}

\author{
SUSAN PERRY \\ The University of Michigan \\ and LISA ROSE \\ Washington University
}

\begin{abstract}
White-faced capuchin monkeys were frequently observed to raid the nests and predate the pups of coatis at two study sites (Santa Rosa National Park and Lomas Barbudal Biological Reserve) in northwestern Costa Rica. Adult monkeys of both sexes were the primary participants in nest-raiding. At Santa Rosa, the original captor of the pup tended to eat the entire carcass, whereas at Lomas Barbudal, the monkeys rapidly became satiated and allowed another monkey to have the carcass. At Lomas Barbudal, there was a tendency for adult females to share preferentially with their own offspring, but only if the offspring were less than 1 year old. Dominance rank of the owner of the carcass relative to the rank of the beggar did not significantly affect the probability of willingly transferring meat to the beggar. In one of two years, carcass theft was more likely to occur when the thief was higher ranking than the carcass owner.
\end{abstract}

Key Words: Cebus capucinus; Nasua narica; Vertebrate predation; Food-sharing.

\section{INTRODUCTION}

Although predation on vertebrates by chimpanzees and baboons has been widely reported (Pan: TeleKI, 1973; Busse, 1976; MCGrew, 1979; Hasegawa et al., 1983; Goodall, 1986; Wrangham \& VAN ZinNicQ BergmanN Riss, 1990; IHOBE, 1992; DE WaAl, 1992; Papio: Stolz \& SaAYMan, 1970; Hausfater, 1976; Strum, 1981), predation on vertebrates by small-bodied primates is fairly rare (BUTYNSKI, 1982). Among smallbodied primates, predation on vertebrates has been most often reported in the Tarsiidae (NIEMITZ, 1979), the Lorisidae (Charles-Dominique, 1977), the Callitrichidae (SUsSMan \& Kinzey, 1984) and in the genus Cebus (C. olivaceous: Fragaszy, 1986; Robinson, 1986; C. apella: IzAWA, 1978; TERBORGH, 1983; C. albifrons: TERBORGH, 1983; C. capucinus: see following). C. capucinus populations studied at three different sites (Barro Colorado Island in Panama, and Santa Rosa National Park and Lomas Barbudal Biological Reserve in Costa Rica) have been reported to prey on lizards, birds (eggs, nestlings, and adults), frogs, squirrels (nestlings and adults), bats, mice, and nestling coatis (OPPENHEIMER, 1968; WatTs, 1977; Newcomer \& DE FARCY, 1985; Mitchell, 1989; Chapman \& Fedigan, 1990; Fedigan, 1990; Rose, 1994; Perry, unpubl. data). Predation on coatis is more risky than predation on other species taken by capuchins because adult coatis, which are twice the size of capuchins, may defend their pups. Coati pups are highly desirable food items because of their presumed high nutritional quality. Because pups are large and conspicuous (they scream as they are being eaten), it is impossible for a monkey to quickly and furtively eat a pup; therefore, there are plenty of opportunities for other monkeys to beg from the carcass owner. The carcass is sometimes shared with the beggars. Within the order 
Primates, food sharing has been noted most frequently in the genus Pan (GoodALL, 1963; TelekI, 1973; SilK, 1979; DE WAAL, 1989) and in the Callitrichidae and Callimico (Brown \& MACK, 1978; Ferrari, 1987; FEISTNER \& PRICE, 1991), but recently Cebus apella has begun to receive attention for its frequent food-sharing behavior in captivity (DE WAAL et al., 1993). In this paper, we report the first observations of food-sharing in wild Cebus, and show how patterns of food transfer relate to kinship and dominance relationships.

\section{METHODS}

The data discussed in this paper were collected at two study sites in Guanacaste Province, Costa Rica: Santa Rosa National Park, and Lomas Barbudal Biological Reserve, both of which consist largely of tropical dry forest with highly seasonal rainfall patterns. Although the two sites receive similar amounts of rainfall, Lomas Barbudal is much more lush due to the numerous rivers and streams running through it. Each of the two study groups at Santa Rosa relied on a single water hole for drinking water during the dry season (December through May). Thus, the monkeys at Lomas Barbudal were presumably under less food and water stress during the dry season than were the monkeys at Santa Rosa. For more detailed descriptions of Santa Rosa and Lomas Barbudal, see JANZEN (1983) and FRANKIE et al. (1988), respectively.

The white-faced capuchin monkey is a small omnivorous primate (OPPENHEIMER, 1968; Freese, 1976; WatTS, 1977; Mitchell, 1989; Chapman \& Fedigan, 1990; Fedigan, 1990; Rose, 1994). Adult females weigh approximately $2.3 \mathrm{~kg}$, and adult males weigh approximately $3.3 \mathrm{~kg}$ (GLANDER et al., 1991). White-faced monkeys live in stable multimale, multi-female social groups and are female philopatric (OPPENHEIMER, 1968; FEDiGAN et al., 1985).

Coatis are omnivorous, diurnal procyonids. Adult males weigh about $6 \mathrm{~kg}$, and adult females are about 10\% smaller than males (KAUfMANN, 1983). Females live in fairly stable social groups for most of the year. However, they nest solitarily, regrouping shortly after the juveniles are capable of independent locomotion (Russell, 1981, 1983; KAUFMANN, 1983). Most coati pups at Santa Rosa and Lomas Barbudal are born in April.

LR observed coati nest-raiding by two capuchin groups (CP and LV) on several occasions in April 1991, in Santa Rosa National Park, during focal follows which were part of a study of sex differences in foraging (Rose, 1994). Predation on coati pups by capuchins has been observed at this site by other researchers since 1983 (NEwCOMER \& DE FARCY, 1985; FEDIGAN, 1990). SP collected data on nest-raiding by one capuchin group during the coati birth seasons in 1992 and 1993 at Lomas Barbudal. Whenever possible, data at Lomas Barbudal were collected in the form of "focal carcass follows," in which a carcass was followed from the time of capture to the consumption of the last scrap of meat. Interactions between the carcass owner and adult coatis, and interactions between the owner and other monkeys (e.g. begging behavior, aggression, food transfer) were recorded on a continuous basis. Since there were up to four pups in a nest, and never more than two observers, it was not possible to conduct complete follows of all carcasses. However, coati pups generally screamed frequently as they were being consumed over a period of several minutes, making them conspicuous to the observers. Monkeys generally stayed near one another as they consumed the pups. Therefore, while conducting a focal carcass follow, it was possible to collect fairly complete ad lib (ALTMANN, 1974) data on the ownership of non-focal carcasses. 
The Mann-Whitney $U$-test was used to compare (1) kin to nonkin dyads and (2) high-ranking to low-ranking corpse owners, with regard to the probability of transferring meat, and all tests were two-tailed.

\section{RESULTS AND DISCUSSION}

Table 1 shows the number of coati nests raided, the number of pups consumed, and the dates of the captures for all three study groups. The number of pups consumed represents a very large percentage of the coati population's birth crop. We estimate that only one nest was left intact within the study group's home range at Lomas Barbudal in 1992, based on the observation that only three pups were seen to be with the group of coatis once the females had rebanded after the birth season. JoEL SAENZ, a coati researcher at Santa Rosa, confirms that white-faced monkeys have a tremendous impact on the coati population (SAENZ, pers. comm.). He inspected the coati nests which he knew to be located in CP group's home range and found that they had all been raided by capuchins. There was some indication that LV group was less active in nest raiding than CP group. Only one raid by LV was observed, and the one monitored nest within the LV range was undisturbed. However, no quantitative intergroup comparison can be made, since observation time during the early nesting season was biased toward CP group, and the number of nests in the LV range was unknown. CP and Lomas groups had similar rates of nest raiding.

In 6 of the 14 successful nest-raiding incidents observed at Lomas Barbudal, the mother coati was absent from the nest when the raid took place. On four occasions, the mother arrived back at the nest after the pups had already been removed. In only four instances of successful nest-raiding was the nest defended by adult coatis. There were also a few unsuccessful nest-raiding attempts in which the monkeys gave up almost as soon as they saw the mother on the nest. Most adults in the study group participated in at least one raid. On one noteworthy occasion, a female monkey with a 4-day-old baby on her back entered a nest guarded by two adult coatis, and she seized two pups from beneath one coati's body. Adult males and females participated approximately equally in nest-raiding. The only adults in the Lomas Barbudal group not seen to participate were the alpha female and a recent immigrant male. Two of the four juvenile males also participated.

At Santa Rosa, only one of the eight raided nests was unguarded by an adult coati. Four nests were defended from the start of the raid. During two, the adult arrived to

Table 1. Coati pups killed by capuchins.

\begin{tabular}{llllll}
\hline $\begin{array}{l}\text { Date in } \\
1991\end{array}$ & $\begin{array}{l}\text { No. of pups in } \\
\text { Santa Rosa }\end{array}$ & $\begin{array}{l}\text { Date in } \\
1992\end{array}$ & $\begin{array}{l}\text { No. of pups in } \\
\text { Lomas Barbudal }\end{array}$ & $\begin{array}{l}\text { Date in } \\
1993\end{array}$ & $\begin{array}{l}\text { No. of pups in } \\
\text { Lomas Barbudal }\end{array}$ \\
\hline April 6 & $5^{\text {a) }}$ & April 7 & 3 & March 30 & 4 (2 nests?) \\
April 15 & 3 & April 11 & 1 & April 6 & 3 \\
April 17 & 2 & April 13 & 4 & April 8 & 1 \\
April 18 & 1,2 & April 25 & 4 & April 9 & 4 \\
April 20 & $4-5$ (2 nests?) & April 26 & 2 & April 11 & 1,3 \\
April 21 & 3 & May 4 & 3 & April 23 & 2,1 \\
Total & $20-21$ pups & Total & 17 pups & Total & 19 pups \\
& $7-8$ nests & & 6 nests & & 8 nests \\
Obs. days & 15 & Obs. days & 19 & Obs. days & 18 \\
\hline
\end{tabular}

a) Killed by Los Valles group, and all the other kills at Santa Rosa were made by Cerca de Piedras group. Obs. days: Number of days on which data were collected, beginning with the first day on which pups were killed and ending on the last day on which pups were killed. 
Table 2. Average number of times members of each age-sex class begged.

\begin{tabular}{llccc}
\hline Age-sex class & $N$ & 1992 & $N$ & 1993 \\
\hline Adult male & 3 & 5.7 & 4 & 2.7 \\
Adult female & 5 & 3.4 & 5 & 3.0 \\
Juvenile male & 4 & 8.7 & 4 & 6.7 \\
Juvenile female & 3 & 2.3 & 3 & 3.7 \\
Infant male & 3 & 17.0 & 3 & 11.7 \\
Infant female & 1 & 14.0 & 1 & 7.0 \\
Baby & 1 & 0 & 1 & 5.0 \\
\hline
\end{tabular}

$N$ : Number of individuals.

defend the nest after the pups had been taken, and in one raid, the start of the raid was unobserved. There was one attempted raid in which the coati succeeded in driving off the monkeys. As in the Lomas Barbudal group, the alpha female of Santa Rosa's CP group never participated in coati nest raids.

With the exception of the three pups killed in May (Lomas Barbudal, 1992), pups were too young to locomote or defend themselves. Therefore, the monkeys did not kill them before consuming them. The screams of the coati pups immediately drew the attention of the other monkeys, who rushed over to beg, and sometimes attracted the mother coati, if she was foraging nearby. At Santa Rosa, the original captor of the pup generally consumed the entire pup, but at Lomas Barbudal, where the monkeys were presumably less foodstressed, it was common for the pup to be abandoned half-eaten. At Lomas, each coati pup carcass had an average of 2.89 owners (range: $1-7$ ), before it was entirely eaten. There was invariably at least one monkey waiting to receive the leftovers. Monkeys begged by approaching the carcass owner, staring at the pup, putting their mouths near the meat, touching and sniffing the pup, and threatening the pup. These mild forms of begging were termed "food interest." More intense begging attempts consisted of biting the pup, pulling pieces of meat or intestines off the carcass, or attempting to pull the entire carcass away from the owner. These incidents were scored as "theft" if the owner resisted by aggressing against the beggar or by attempting to get the meat back. If the owner did not resist the beggar, it was termed "tolerated food transfer." Rarely, the owner would set meat down in front of the beggar as if giving it to him.

For the purposes of examining patterns of food transfer, we restrict our analyses to the Lomas Barbudal data set, in which the data on social interactions with juveniles and infants are more complete. When all of the owner/beggar dyads are plotted on a matrix of all group members, it becomes apparent that not all age-sex classes are equally likely to participate in coati-related social interactions. Juvenile males and infants were by far the most frequent participants, particularly as beggars (Table 2), although juvenile males were

Table 3. Average number of times individual members of each age-sex class owned a pup.

\begin{tabular}{lllll}
\hline Age-sex class & $N$ & 1992 & $N$ & 1993 \\
\hline Adult male & 3 & 5.3 & 4 & 2.2 \\
Adult female & 5 & 4.0 & 5 & 2.8 \\
Juvenile male & 4 & 4.5 & 4 & 4.0 \\
Juvenile female & 3 & 1.3 & 3 & 1.0 \\
Infant male & 1 & 0 & 1 & 1.0 \\
Infant female & 3 & 1.3 & 3 & 1.3 \\
Baby & 1 & 0 & 1 & 0 \\
\hline
\end{tabular}

$N$ : Number of individuals. 
Table 4. Proportion of begging incidents in which meat was shared.

\begin{tabular}{lllll}
\hline Age-sex class & $N$ & 1992 & $N$ & 1993 \\
\hline Adult male & 3 & .12 & 3 & .59 \\
Adult female & 5 & .14 & 4 & .31 \\
Juvenile male & 3 & .29 & 4 & .36 \\
Juvenile female & 1 & 0 & 2 & .50 \\
Infant male & 3 & .33 & 2 & .25 \\
Infant female & - & - & 1 & .33 \\
\hline
\end{tabular}

$N$ : Number of individuals.

frequent owners as well (Table 3). Adult males virtually never begged from one another. There was no tendency for any particular age-sex class to share more than any other age-sex class (Table 4).

For the Lomas Barbudal sample, we tested the hypothesis that owners transfer food (i.e. voluntarily share food or tolerate transfer of food) more often to kin than to non-kin by examining those dyads consisting of adult females and juveniles under 3 yrs of age as of 1993 (i.e. those for which maternity was known). Kin dyads (i.e. mother-infant dyads) were compared to non-kin female-infant dyads with regard to the proportion of begging instances in which food was transferred. In 1992, there was a marginally significant trend for kin to be preferred (kin: $\chi=.583, n=3$; non-kin: $\chi=.075, n=11$; Mann-Whitney $U: U=6.5, p=.0511$ ), but in 1993 there was no kin-related effect (kin: $\chi=.333, n=3$; non-kin: $\chi=.200, n=5$; Mann-Whitney $U: U=6.5, p=.6933$ ). The stronger result for 1992 may be due to the fact that the five infants in the sample were all a year younger in 1992 than in 1993; perhaps mothers are more willing to share with their offspring when they are younger. Indeed, there was nearly twice as much food transfer overall to infants in the 1992 sample as in the 1993 sample.

We also looked for rank-related effects on the likelihood of transferring meat. First we examined whether voluntary food transfer (i.e. either active food sharing or tolerated food transfer) was more likely when the owner was higher ranking or lower ranking than the beggar. Results were non-significant in opposite directions for the two years (1992: owner higher-ranking: $\chi=0.15, n=64$; owner lower-ranking: $\chi=.21, n=25$; Mann-Whitney $U: U=775, p=.759$; 1993: owner higher-ranking: $\chi=0.18, n=51$; owner lower-ranking: $\chi=0.07, n=27$; Mann-Whitney $U: U=570, p=.070$ ). There was a significant tendency for more theft to occur when the owner was lower-ranking than the beggar in 1992 (owner higher-ranking: $\chi=0.03, n=64$; owner lower-ranking: $\chi=0.28, n=25$; Mann-Whitney $U: U=606.5, p=.001$ ), but this result was non-significant in 1993 (owner higher-ranking: $\chi=0.01, n=51$; owner lower-ranking: $\chi=0.07, n=27$; Mann-Whitney $U: U=662.5, p=.475$ ).

Predation on coatis by capuchins is striking for several reasons. With the possible exception of chimpanzee predation on red colobus monkeys (WRANGHAM \& VAN ZINNICQ BERGMANN RISS, 1990; STANFORD, 1994), this is the heaviest documented impact of predation by primates on a population of large-bodied mammals. Unlike most examples of vertebrate predation by small-bodied primates, predation on coatis represents a considerable potential risk to the predator. Although coatis are considerably larger than capuchins and have quite formidable jaws, coatis are not as agile as capuchins, and apparently do not see well enough to outmaneuver them in the trees. The data on food-sharing presented here are the first for a wild Cebus population. Methodological differences make direct comparison with DE WAAL et al.'s 1993 study of food-sharing in captive Cebus 
apella difficult, but it appears that active sharing was slightly more common in the C. apella group than in the C. capucinus group. Rates of food transfer in C. capucinus are definitely lower than those reported for chimpanzees (TELEKI, 1973; DE WAAL, 1989).

Acknowledgments. We thank J. MAnson and J. Gros-Louis for assistance in data collection. F. DE WaAl, J. Macedonia, J. Manson, N. Peters, and R. Smolker commented on earlier versions of the manuscript. Research was supported by grants from The Leakey Foundation (SP), three units of the Rackham Graduate School (SP), The National Geographic Society (B. SmUTS and SP), The University of Michigan Alumnae Society (SP), and a NSERC post-graduate scholarship (LR). Thanks to the Servicio de Parques Nacionales, the Area de Conservación Guanacaste and the Area de Conservación Tempisque for permitting us to do research in the Costa Rican park system. G. Frankie, J. Frankie, K. Glander, J. Mitani, B. Smuts, and Amigos de Lomas Barbudal provided financial or logistical assistance in the field.

\section{REFERENCES}

Altmann, J., 1974. Observational study of behavior: sampling methods. Behaviour, 49: 227-265. BRown, K. \& D. MACK, 1978. Food sharing among captive Leontopithecus rosalia. Folia Primatol., 29: $268-290$.

Busse, C., 1976. Chimpanzee predation as a possible factor in the evolution of red colobus monkey social organization. Evolution, 31: 907-911.

ButYNSKI, T. M., 1982. Vertebrate predation by primates: a review of hunting patterns and prey. $J$. Human Evol., 11: $421-430$.

Chapman, C. A. \& L. M. Fedigan, 1990. Dietary differences between neighboring Cebus capucinus groups: local traditions, food availability, or response to food profitability? Folia Primatol., 54: $177-186$.

Charles-Dominique, P., 1977. Ecology and Behavior of Nocturnal Primates. Columbia Univ. Press, New York.

DE WAAL, F. B. M., 1989. Food sharing and reciprocal obligations among chimpanzees. J. Human Evol., 18: $433-459$.

- 1992. Appeasement, celebration, and food sharing in the two Pan species. In: Human Origins, T. Nishida, W. McGrew, P. Marler, M. Pickford, \& F. de Waal (eds.), Univ. of Tokyo Press, Tokyo, pp. 37-50.

, L. M. Luttrell, \& M. E. CAnfield, 1993. Preliminary data on voluntary food sharing in brown capuchin monkeys. Amer. J. Primatol., 29: 73-78.

FedigAn, L. M., 1990. Vertebrate predation in Cebus capucinus: meat eating in a neotropical monkey. Folia Primatol., 54: 196-205.

, L. Fedigan, \& C. A. Chapman, 1985. A census of Alouatta palliata and Cebus capucinus in Santa Rosa National Park, Costa Rica. Brenesia, 23: 309-322.

Feistner, A. T. C. \& E. C. Price, 1991. Food offering in New World primates: two species added. Folia Primatol., 57: 165-168.

Ferrari, S., 1987. Food transfer in a wild marmoset group. Folia Primatol., 48: 203-206.

FraGASZY, D. M., 1986. Time budgets and foraging behavior in wedge-capped capuchins (Cebus olivaceus): age and sex differences. In: Current Perspectives in Primate Social Dynamics, D. M. Taub \& F. A. King (eds.), Van Nostrand Reinhold, New York, pp. 159-174.

Frankie, G. W., S. B. Vinson, L. E. Newstrom, \& J. F. Barthell, 1988. Nest site and habitat preferences of Centris bees in the Costa Rican dry forest. Biotropica, 20: $301-310$.

FreEse, C. H., 1976. Food habits of white-faced capuchins Cebus capucinus L. (Primates: Cebidae) in Santa Rosa National Park, Costa Rica. Brenesia, 10/11: 43 - 56.

Glander, K. E., L. M. Fedigan, L. Fedigan, \& C. Chapman, 1991. Field methods for capture and measurement of three monkey species in Costa Rica. Folia Primatol., 57: 70-82.

GoodAlL, J., 1963. My life among wild chimpanzees. Nat. Geograph., 124: 272-308. 
1986. The Chimpanzees of Gombe: Patterns of Behavior. Harvard Univ. Press, Cambridge, Massachusetts.

Hasegawa, T, M. Hiraiwa-Hasegawa, T. Nishida, \& H. Takasaki, 1983. New evidence of scavenging behavior of wild chimpanzees. Cur. Anthropol., 24: 231-232.

HAUSFATER, G., 1976. Predatory behavior of yellow baboons. Behaviour, 56: 44-68.

IHOBE, H., 1992. Observations on the meat-eating behavior of wild bonobos (Pan paniscus) at Wamba, Republic of Zaire. Primates, 33: 247-250.

IZaWa, K., 1978. Frog-eating behavior of wild black-capped capuchin (Cebus apella). Primates, 19: $633-642$.

Janzen, D. H., 1983. Costa Rican Natural History. Univ. of Chicago Press, Chicago.

Kaufmann, J. H., 1983. Nasua narica. In: Costa Rican Natural History, D. H. Janzen (ed.), Univ. of Chicago Press, Chicago, p. 816.

MCGrew, W. C., 1979. Evolutionary implications of sex differences in chimpanzee predation and tool use. In: The Great Apes, D. A. Hamburg \& E. R. McCown (eds.), Benjamin/Cummings, Menlo Park, California, pp. 441-463.

Mitchell, B. J., 1989. Resources, group behavior, and infant development in white-faced capuchin monkeys, Cebus capucinus. Ph.D. diss., Univ. of California, Berkeley.

NewCOMER, D. M. \& D. D. DEFARCX, 1985. White-faced capuchin (Cebus capucinus) predation on a nestling coati (Nasua narica). J. Mammal., 66: 185-186.

Niemitz, C., 1979. An outline of the behaviour of Tarsius bancanus. In: The Study of Prosimian Behavior, G. A. Doyle \& R. D. Martin (eds.), Academic Press, New York, pp. 631-660.

OpPenheimer, J. R., 1968. Behavior and ecology of the white-faced monkey Cebus capucinus on Barro Colorado Island, Canal Zone. Ph.D. diss., Univ. of Illinois, Urbana, Illinois.

Robinson, J. G., 1986. Seasonal variation in use of time and space by the wedge-capped capuchin monkey, Cebus olivaceus: implications for foraging theory. Smithson. Contrib. Zool., 431: 1-60.

Rose, L. M., 1994. Sex differences in diet and foraging behavior in white-faced capuchins, Cebus capucinus. Int. J. Primatol., 15: 95-114.

Russell, J. K., 1981. Exclusion of adult male coatis from social groups: protection from predation. J. Mammal., 62: 206-208.

- 1983. Altruism in coati bands: nepotism or reciprocity? In: Social Behavior of Female Vertebrates, S. WASSER (ed.), Academic Press, New York, pp. 263-290.

SILK, J., 1979. Feeding, foraging, and food sharing behavior of immature chimpanzees. Folia Primatol., 31: 123-142.

STANFORD, C. B., 1994. The influence of chimpanzee predation on red colobus group size and behavioral ecology. Amer. J. Phys. Anthropol., suppl. 18, p. 186.

Stolz, L. P. \& G. S. SaAYMAn, 1970. Ecology and behavior of baboons in the northern Transvaal. Ann. Transvaal Mus., 26: 99-143.

Strum, S. C., 1981. Processes and products of change: baboon predatory behavior at Gilgil, Kenya. In: Omnivorous Primates: Gathering and Hunting in Human Evolution, R. S. O. HARDING \& G. TELEKI (eds.), Columbia Univ. Press, New York, pp. 255-302.

Sussman, R. W. \& W. G. Kinzey, 1984. The ecological role of the Callitrichidae: a review. Amer. $J$. Phys. Anthropol., 64: 419-449.

TELEKI, G., 1973. The Predatory Behavior of Wild Chimpanzees. Bucknell Univ. Press, Lewisburg, Pennsylvania.

Terborgh, J., 1983. Five New World Primates. Princeton Univ. Press, Princeton, New Jersey.

WaTTS, D. P., 1977. Activity patterns and resource use of white-faced Cebus monkeys (Cebus capucinus) on Barro Colorado Island, Panama Canal Zone. M.A. thesis, Univ. of Chicago, Chicago.

Wrangham, R. W. \& E. VAN ZinNICQ BERGMANN Riss, 1990. Rates of predation on mammals by Gombe chimpanzees, 1972-1975. Primates, 31: 157-170.

Authors' Names and Present Addresses: Susan Perry, Department of Anthropology, University of California, Los Angeles, 405 Hilgard Avenue, Los Angeles, California 90024-1553, U. S. A.; Lisa Rose, Department of Anthropology, Washington University, St. Louis, Missouri 63130, U. S. A. 